\title{
Rural landscapes and agrarian spaces under soybean expansion dynamics: a case study of the Santarém region, Brazilian Amazonia
}

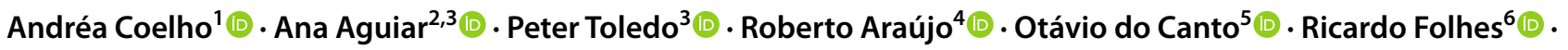 \\ Marcos Adami ${ }^{7}$ iD
}

Received: 1 September 2020 / Accepted: 25 July 2021/ Published online: 7 October 2021

(c) The Author(s) 2021, corrected publication 2022

\begin{abstract}
Following the boom of soybean production from 2000 to 2006 in the Santarém region of the Brazilian Amazon, the mechanized agricultural area remained stable, unlike other regions. Deforestation was controlled, but this initial expansion led to the restructuring of the agrarian space in the region. Given this scenario, we aimed to understand the mechanized agricultural expansion effects in the region by comparing the periods 1999-2007 and 2007-2015. Our hypothesis was that it impacted heterogeneous actors and land tenure categories. We combined multi-temporal land change maps derived from remote sensing to land tenure information to evaluate how land change transitions differed over time, both in public (traditional and sustainable use official settlements) and private areas. In private areas, we observed a $12 \%$ reduction in forest cover in 1999-2007 and a 2.5\% reduction in 2007-2015. In sustainable use settlements, forest loss was only 3\% and 2\% in each period, respectively. Mechanized agriculture occupied areas of family farming (42\%), secondary vegetation (20\%), pasture (20\%), and forest areas (18\%). Family farming lost most of the area to other uses. Within settlements, the area of family farming increased by $50 \%$ at the expense of the forest area. We conclude that the rise and fall of deforestation in the Brazilian Amazon hide multiple social and territorial processes. Understanding such dynamics is critical for establishing measures toward a sustainable future.
\end{abstract}

Keywords Brazilian Amazon $\cdot$ Soybeans $\cdot$ Deforestation $\cdot$ Land-use change $\cdot$ Smallholders

Communicated by Jasper van Vliet

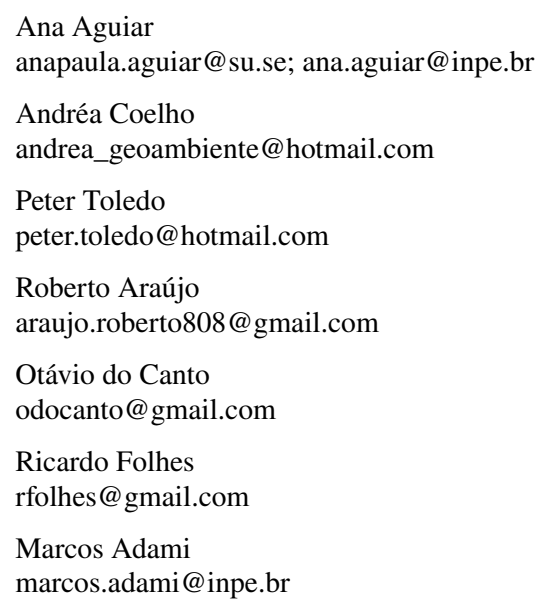

1 Programa de Pós-Graduação em Ciências Ambientais, Instituto de Geociências, Universidade Federal do Pará, Campus Universitário do Guamá, s/n - Universitário, Belém, Pará CEP 66075-110, Brazil
2 Stockholm Resilience Centre, Stockholm University, Kräftriket, 2B 10405 Stockholm, Sweden

3 Instituto Nacional de Pesquisas Espaciais (INPE), Av. dos Astronautas 1758 - Jardim da Granja, São José dos Campos, São Paulo CEP 12227-010, Brazil

4 Museu Paraense Emílio Goeldi, Centro de Ciências Humanas, Av. Perimetral, 1901, Terra Firme, Belém, Pará CEP 66077-830, Brazil

5 Núcleo de Meio Ambiente, Universidade Federal Do Pará, Setor Profissional, R. Augusto Corrêa, 1, Guamá, Belém, Pará CEP 66075-110, Brazil

6 Núcleo de Altos Estudos Amazônicos (NAEA), Setor Profissional, R. Augusto Corrêa, 1, Guamá, Belém, Pará CEP 66075-110, Brazil

7 Instituto Nacional de Pesquisas Espaciais (INPE), Parque de Ciência e Tecnologia do Guamá, Belém, Pará, Brazil 


\section{Introduction}

The Brazilian Amazon covers an area of approximately $5,000,000 \mathrm{~km}^{2}$ comprising ecosystems of incalculable value with great cultural and natural resources, while harboring immense varieties of flora and fauna. High rates of forest suppression have reduced biodiversity, disrupted biochemical cycles, and increased carbon emissions, in contribution to the region garnering attention in recent decades (Aragão et al. 2018; Nobre et al. 2016).

This process began in the 1960s, when the region suffered direct intervention on behalf of the federal government to physically and economically integrate this region into the country, through development policies that stimulated land use and land cover (LULC) change and converting forest into farming land (Becker 2015). As a result, there was a significant increase in deforestation rates in the Amazon region, achieving two peak annual increments of $29,059 \mathrm{~km}^{2}$ and $27,772 \mathrm{~km}^{2}$ in 1995 and 2004, respectively (INPE 2021). The second increment directed the government's attention toward environmental actions and policies, such as the Plan of Action for Prevention and Control of Deforestation in the Legal Amazon (PPCDAM), the Sustainable Amazônia Plan (PAS), the Sustainable BR-163, the creation of the Sustainable Forest District (DFS), and the implementation of settlement and execution projects by the Ecological Economic Zoning of the BR-163 area of influence (ZEE BR-163), with the objective of mitigating the process (Mello and Artaxo 2017).

Additionally, strong pressures from the environmental protection sector have also been directed at agribusiness. These pressures are aimed at adopting conduct and procedures that can mitigate various environmental problems arising from agricultural activities (Akabane et al. 2010; Santos 2010). These actions included the Soy Moratorium (Gibbs et al. 2015), signed by the Brazilian Association of Vegetable Oil Industries (ABIOVE) and the National Association of Grain Exporters (ANEC), in 2006. Driven by pressure from NGOs in the agribusiness productive sector, this agreement made member companies committed to not buying soybeans produced in the deforested Amazon Biome after July 2006 (Garrett and Rausch 2016; Rudorff et al. 2012). This date has then been adjusted to July 2008, according to the Brazilian Forest Code. In addition to the policies induced by international markets and government, regional demands of environmental groups and social movements are also included in this context, which consider the maintenance of natural resources as a fundamental condition for social reproduction of local groups, such as indigenous people and ribeirinhos (traditional people who live in the surrounding rivers). This highlights a close relationship among sustainability, natural landscapes, and environmental services (Araújo et al. 2019). As a result of the combined actions of the government, civil society, and markets (Nolte et al. 2017; Ewers et al. 2008), deforestation has fallen dramatically, hovering around $7000 \mathrm{~km}^{2}$. However, this has changed and we observed increasing deforestation rates, exceeding $10,000 \mathrm{~km}^{2}$ recently (INPE 2019).

In Pará, deforestation is linked to productive activities and land occupation processes, including extensive livestock, family farming, land grabbing, road opening, and the recent expansion of mechanized grain agriculture, mainly soybeans, whose production was the target of state encouragement policies, especially from 1995 to 2002 (Castro 2005; Rivero et al. 2009). Santarém is a city in western Pará, located in the area of influence of the BR-163 road, where the production of soybeans started around 2000 led by the migration of capitalized farmers from other states. By 2005, the region had already accounted for $33 \%$ of the state's production of this crop. However, this expansion did not occur in "empty" territory. Santarém is an old occupation area situated in the margins of the Amazon and Tapajos Rivers, close to their confluence. Since the 1970s, a mosaic of special areas (30 settlements and a national forest) has been defined in the region, for organizing space and rationalizing the use of natural resources, creating socio-spatial dynamics combining public and private areas.

Mechanized grain agriculture requires large extensions of contiguous flat areas, and such expansion has led to a restructuring of the agrarian space in the region. It includes replacement of family farming, secondary vegetation, and pasture by monoculture. Areas of primary forest were advanced, thus increasing deforestation (Song et al. 2021; Coelho 2009).

Although much has been written about the impacts of the actions discussed above on deforestation decline, little is known about how regional LULC dynamics have been affected. Impacts of such dynamics on heterogeneously different actors and land tenure categories are explored. This paper aims to understand the effects of public policies and societal actions on LULC changes in addition to their role in Santarém's space configuration, comparing 1999-2007 and 2007-2015.

First, we present a review of the soy expansion process and the main measures, both governmental and civil, in response to the increase in deforestation in the first period studied. We then present the methods employed to quantify and analyze the transitions that occurred in each period. The results are presented for the entire region and stratified into public and private land categories. Finally, we discuss the findings in relation to ongoing processes at the regional scale, including other agribusiness frontiers. 


\section{Background: Considering soybean in the Santarém region in the context of public policies to combat deforestation in the Amazon}

Consolidation of the agricultural frontier in the Mato Grosso Cerrado in the 1990s fostered expansion toward the Amazon, motivated by the need for new areas for planting of grains and rapidly growing cattle. It is within this context that grain producers in the central and southern areas of the country began to invest in agricultural production around the Santarém region, attracted by a combination of factors, such as the development of soybean cultivars adapted to the physical characteristics of the area, the increase in international value of soybeans, regional agricultural suitability, low land prices, and government incentives. Additionally, the logistical conditions offered by the installation of the multinational Cargill bulk port, opened in 2003 in Santarém, favored a migratory wave of producers who had the experience and capital to begin using land for this purpose (Gayoso 2012; Walker et al. 2009).

Until the late 1990s, LULC in the region's municipalities was based on small-scale, subsistence-oriented family farming, surplus trade, plant extraction especially wood and latex, and livestock. The main temporary crops were cassava, beans, corn, and rice. From 1997, soybean began to initially appear in official statistics, before becoming one of the main temporary crops in the region from 2003 (Coelho 2009).

Introduction of grain agriculture in the region was accompanied by increased deforestation and land grabbing. This triggered a wave of protests and indictments by non-governmental organizations (NGOs), entities linked to social movements, such as the Comissão Pastoral da Terra (CPT), linked to the National Commission of Bishops of Brazil (CNBB) and the Rural Workers Union (Coelho 2009). In 2004, the Brazilian government launched the Action Plan for the Prevention and Control of Deforestation in the Legal Amazon (PPCDAm), for continuously reducing deforestation and creating the necessary conditions for transitioning to a sustainable development model in the Legal Amazon. The actions articulated around three thematic axes: (i) land and territorial planning, (ii) environmental monitoring and deforestation control, and (iii) promoting sustainable and productive activities.

A brief history of public policies in the region is shown in Fig. 1. Among these policies, the 2005 federal government decree of the Latin American Population Association (ALAP) is particularly relevant to the struggle against deforestation, and directly affects the LULC changes in the Santarém region. ALAP inhibited the activities and enterprises potentially causing environmental degradation in a studied area to create a conservation unit (COU). The BR-163 Economic Ecological Zoning was another important measure that supported the Sustainable Amazon Plan (PAS), and the creation of an administrative process for environmental infraction, called the Infringement and Embargo Notice. This refers to the embargo of developments or activities that imply deforestation, suppression, or forest degradation when administrative or criminal infractions against the flora are found (MMA 2008a).

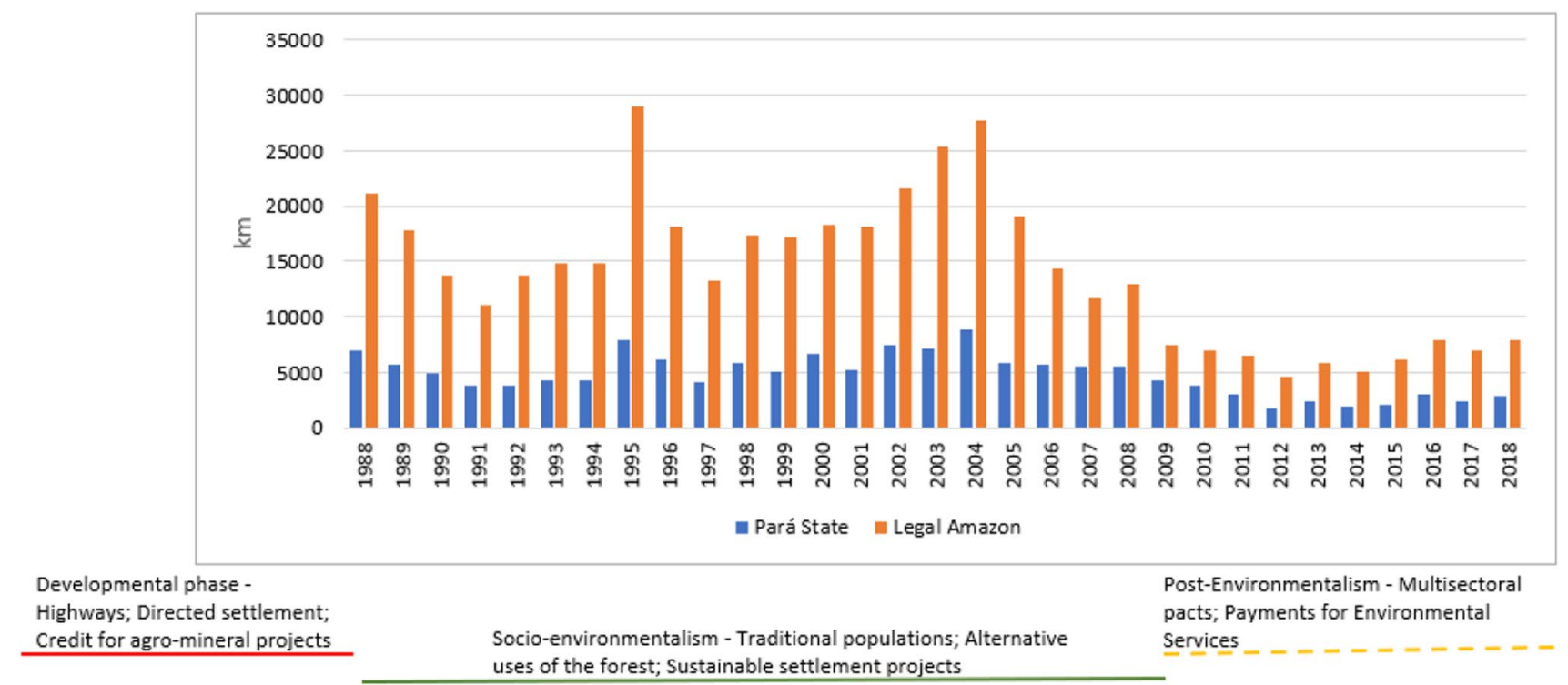

Fig. 1 Deforestation rate in the Legal Amazon and Pará State (2000-2018) and Institutional framework of Santarém (modified from Araújo and Léna (2010) 
Creating several special areas was also a government measure with a strong regional impact, especially for the new modalities of agrarian reform settlements (Table 1), whose rules of use prioritize the development of environmentally sustainable activities (for example, the AgroExtractive Settlement Projects (ASP) and the Sustainable Development Project (SDP)). The SDP and ASP modalities mainly feature real use rights concessions, which benefit families residing in public and inalienable areas, prioritizing extractive and agricultural subsistence activities for families. This is a strategy that attempts to combine human occupation and environmental preservation, an integral concept of the socio-environmental model discussed by Araújo and Léna (2010).

The socio-environmental model emphasizes the importance of issues related to preservation of the environment and biodiversity (Araújo and Léna 2010). It is associated with a discursive recomposition of the identity of certain populations. This process is based on the idea that the key to alternative development in the Amazon would be virtually embedded in local knowledge systems and practices. Of the 30 settlements established since the 1970s in Santarém, 21 were created after 2006. This justifies containing deforestation and land grabbing, due to the introduction of grains in the region and the expectation of a new asphalt road, BR-163. However, in 2007, due to the various arbitrary acts committed during the creation of these projects, the Federal Public Prosecutor's Office filed an unfamiliar precautionary action to suspend license applications for creation of new settlements together with licenses issued between 2005 and 2007. The settlement embargo made it impossible for settlers to access certain public policies, such as those aimed at agricultural credit and infrastructure, leading them to precarious livelihoods and thus favoring agreements with loggers for irregular logging (Brito and Guerra 2015).

Negative environmental repercussions that involved the introduction of soybean cultivation in the Amazon region, coupled with an increase in deforestation rates, also affected the market. Importers, pressured by the civil society of their countries, especially the European consumer market, demanded environmental and social certification for soybeans produced in the Amazon. Thus, the Soy Moratorium was signed on July 24, 2006, which consisted of a pact between the ABIOVE, the ANEC, and their respective associates (including the main international soy traders: Cargill, Bunge, ADM, Dreyfus, and the Brazilian Maggi Group). The Soy Moratorium provides for the embargo on soybeans coming from new deforested areas of the Amazon from 2008, and from private properties where there are any environmental or social issues, such as slave labor or embargo (Rudorff et al. 2012; Garrett and Rausch 2016).

The actions put forth in the government provisions and the Soy Moratorium significantly reduced the Amazon deforestation rate (Gibbs et al. 2015), and this could be attested by the Brazilian Satellite Rainforest Monitoring Project (INPE 2019). The annual rate decreased from $27,772 \mathrm{~km}^{2}$ in 2004 to $10,129 \mathrm{~km}^{2}$ in 2019 , accounting for 63.52\% and 53\% reductions in the Legal Amazon and Pará respectively (INPE 2019).

According to Ministry of the Environment (2016), the actions with the greatest impact on deforestation reduction refer to the environmental monitoring and control axis in the 2nd phase of PPCDAm, achieving this through the development and efficiency of the near real-time deforestation detection (DETER) system and agility of integrated actions to monitor deforestation and combat organized crime (Assunção et al. 2013, 2015).

These measures showed an effect on grain production in the Santarem region, especially in the municipalities of Santarém and Belterra. According to IBGE data, the annual average of soybean production stabilized at $28,000 \mathrm{t}$ as of 2006 , which represents a decrease of $16.42 \%$ over the previous period. However, the area destined for soybeans continued to increase in Pará. This caused the Santarém

Table 1 Categories of settlement projects in the Amazon

\begin{tabular}{lc}
\hline Category & Goal \\
\hline FLONA (National Forest) & $\begin{array}{c}\text { Conservation Unit for Sustainable Use. Intended for the collective use of land, with rules of use of } \\
\text { the territory that provide for activities aimed at the subsistence of traditional populations in the } \\
\text { area } \\
\text { Designed for agrarian reform clients, where the rules of land use provide for family farming. The } \\
\text { plots for these families vary up to } 100 \text { ha and individual land tenure is planned } \\
\text { This modality is not regularized, and among the rules of use of the territory, it is foreseen that the } \\
\text { use is collective }\end{array}$ \\
CSP (Collective Settlement Project) & $\begin{array}{c}\text { Intended for traditional populations that have the extraction of natural resources as a basis for their } \\
\text { reproduction. In this modality, family farming is allowed } \\
\text { Intended for low-impact activities, such as plant and animal extraction, where each settled family } \\
\text { can only use up to 3 ha of land per year for the development of activities aimed at subsistence } \\
\text { agriculture }\end{array}$ \\
\hline
\end{tabular}


region's share in state production to fall to $6.84 \%$, whereas state production grew by $534 \%$, expanding mainly in the southeastern part of the state (see Online Resource, Fig.1 ). In this paper, we seek to understand how such measures are reflected in the processes of LULC change in the region underlying the deforestation data, comparing the 1999-2007 and 2007-2015 periods.

\section{Material and methods}

\section{Study area}

The Santarem region is located in the west of the state of Pará at coordinates W 55 $01^{\prime} 42^{\prime \prime} / \mathrm{W} 53^{\circ} 45^{\prime} 51^{\prime \prime}$ and S $02^{\circ} 22^{\prime} 39^{\prime \prime} / \mathrm{S} 03^{\circ} 37^{\prime} 39^{\prime \prime}$, covering an area of 19,296.26 $\mathrm{km}^{2}$, comprising parts of the municipalities of Santarém, Belterra, Prainha, Uruará, Placas, and Mojuí dos Campos (Fig. 2). The landscape in the region was mostly pasture and small-scale agriculture, distributed among communities on both land and river banks, including the ribeirinhos (riverine) communities. The arrival of capitalized farmers shifted the focus on grain cultivation, especially soybeans and rice in the late 1990s, and intensified LULC dynamics and restructuring of the local agrarian space (Côrtes and D'Antonna 2016; Garrett and Rausch 2016), including the creation of several settlement projects.

The 30 agrarian reform settlement projects currently present in the region, in whole or in part, belong to the following categories: settlement project (SP), common settlement project (CSP), ASP, and SDP. Created in 1971, they accounted for $43 \%$ of the total area. The National Forest, FLONA Tapajós, was also created in 1974 (Table 1). These units have different land-use rules and aim to serve different populations (Folhes et al. 2015).

In this paper, we seek to understand how these myriad actors and rules of use contributed to the LULC dynamics in 2000-2007 and 2007-2015. Hence, the units were classified as follows:

1. Restricted and forest use settlements (ASP, SDP, FLONA) aimed at populations that traditionally live in the areas intended for their implementation. FLONA, although a conservation unit, is also considered a settlement for traditional populations.

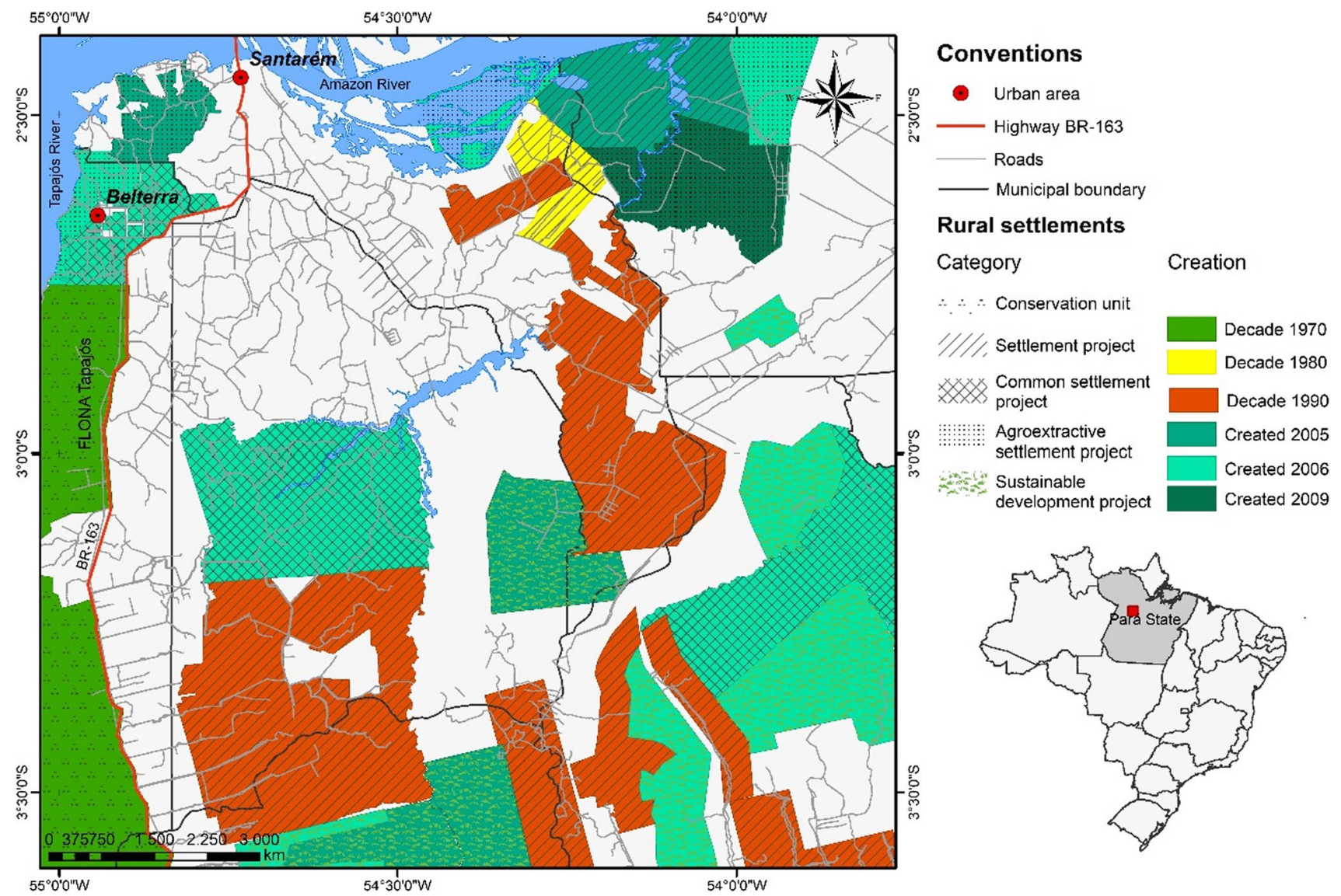

Fig. 2 Study area and categories of spatial areas: (a) different modalities that make up the region; (b) creation dates 
2. Conventional agricultural units (SP, CSP) for small family farmers.

\section{Methodology}

\section{Land use and land cover mapping}

For the development of this research, a geographic database was constructed with LULC vector data for 1999 and 2007 (Coelho 2009). To update the LULC time series, we built a 2015 map. Thus, we used the orbit-point 227-062 Landsat 8-OLI image obtained on August 14, 2015. This was selected due to the least cloud obstruction, available from the US Geological Survey (USGS) website, which has been orthorectified and has a WGS84 projection maintained (Kalluri et al. 2000). The image was audited according to data provided by NASA after selection (Assessment of NASA - USGS Global Land Survey (GLS) datasets).

Image processing and data generation were performed using the TerraAmazon 4.5.1 geographic information system software (www.dpi.inpe.br/terralib). The following classes were defined, following Coelho (2009): (i) Mechanized agriculture: refers to mechanized grain agriculture, mainly soybeans, in which sophisticated production techniques, machinery, and agricultural implements are employed; (ii) forest: primary native vegetation, which has not undergone significant disturbances; (iii) secondary vegetation: natural regeneration of vegetation after removal of the primary forest or abandonment of the cultivated area; (iv) family farming: family farming in a consortium with secondary vegetation, which may or may not be associated with livestock, and due to the spatial resolution of the satellite images used, it is not possible to discriminate between them; and (v) pasture: planted in the development stage with a predominance of herbaceous vegetation, may or may not be associated with the presence of sparse shrub vegetation and/or degradation.

Mapping was performed using the visual photo interpretation method, considering patterns, such as tint, color, shape and size, pattern, and texture. In this method, recognition patterns are used as guiding factors in the process of recognizing and identifying targets on the Earth's surface through aerial photography or satellite imagery (Panizza and Fonseca 2011).

\section{Quantification and analysis of transitions by land category}

For the analysis of the relationship between landscape changes and land structure, the analyses were performed in different partitions of the space for 1999-2007 and 2007-2015:
- Partition A: whole study area;

- Partition B: study area, excluding settlements;

- Partition C: Restricted/forest use settlements (SDP, ASP, and FLONA);

- Partition D: Conventional agricultural settlements (SP, CSP);

For each space partition, we quantified the area of each LULC class based on the "class measurement" function, after obtaining the classified thematic images for the three dates. Subsequently, transitions between classes were quantified by crossing thematic maps of consecutive dates (cross tabulation) based on the spatial distribution of their thematic information, generating matrices of changes. A representation of the possible transitions between classes observed in the study area is presented in the Online Resource S2 (Fig. 2).

To support the analysis, we combined the following spatial information: limits of protected areas, settlement projects, rural environmental register, roads, municipal headquarters, and localities (Chico Mendes Institute for Biodiversity Conservation (ICMBio), National Institute for Colonization and Agrarian Reform (INCRA), and the Brazilian Institute of Geography and Statistics (IBGE)). These analyses were supported by scientific literature and official documents.

In addition to the activities related to the analysis of documents and satellite images, the team promoted several field excursions in the laboratory between 2007 and 2017, mainly in rural properties and settlements, and in the municipalities of Santarém, Belterra, Juruti, Uruará, Plaques, and Mojuí dos Campos. It is also noteworthy that surveys of field samples assess the interpretation of satellite images. Additionally, a thorough work of community characterization was carried out. A total of 298 forms were completed involving 12 communities, distributed in places that suffered direct interference from soybeans plantation expansion and communities that had not undergone this process.

\section{Results and discussion}

\section{Forest loss in partitioning}

According to the results obtained, there was a $56 \%$ increase in the total deforested area in the Santarém region during 1999-2015. However, deforestation was advancing during 1999-2007, when $1217 \mathrm{~km}^{2}$ was deforested. During 2007-2015, deforestation was $342.35 \mathrm{~km}^{2}$, which corresponds to a $72 \%$ reduction compared to deforestation in the previous period. This implies reductions of $9 \%$ and 3\% in forest cover during 1999-2007 and 2007-2015, respectively. 
The mechanized agricultural class was absent in 1999 (Fig. 2a). In 2007, it occupied an area of $597 \mathrm{~km}^{2}$ (3.77\%) and $702 \mathrm{~km}^{2}(4.44 \%)$ in 2015, showing an increase of $17.68 \%$ during this period. In 2007 , the family farming class increased by $4 \%$ compared to 1999 and decreased by $4.61 \%$ in the subsequent period. Therefore, its area remained close to the initial level, though with a modified spatial pattern. We highlight the dynamics of secondary vegetation and pasture classes. Secondary vegetation increased by $75 \%$ during 1999-2015. The pasture area increased by $76 \%$ during 1999-2015 (see Online Resource S3, Fig. 3).

However, the dynamics of forest loss were heterogeneous for different partitions of the study area. If we exclude settlements (partition B), this percentage rises to $12 \%$ during 1999-2007. During 2007-2015, the reduction is $2.5 \%$ if we exclude settlements (see Online Resource S3, Fig. 4). The values are similar in the traditional settlements (partition C): $10 \%$ and $4 \%$ in the first and second periods, respectively. However, in the sustainable use partition (partition D), forest loss was only $3 \%$ and $2 \%$ in each period, respectively (Fig. 3).

Although proportionally smaller, analysis of the LULC change of sustainable settlements indicates that the established rules of LULC were not met. This is especially true in the first period, in which $108.89 \mathrm{~km}^{2}$ of forest was converted for other uses, with emphasis on mechanized agriculture, which occupied $34.59 \%$ of the area, followed by pasture $(31.25 \%)$ and family farming $(22.36 \%)$ (see Online Resource S3, Fig. 5).

In the subsequent period, of the $50.24 \mathrm{~km}^{2}$ deforested area, pasture and family farming occupied $69.12 \%$ and $8.35 \%$ of the area, respectively. Although new conversions to mechanized agriculture declined in the second period, there were still $14.38 \mathrm{~km}^{2}$ of this class in sustainable settlement areas.

These results illustrate the frailty of some of these units, created as part of the conservation strategy in the socioenvironmental model, several of them being targeted by

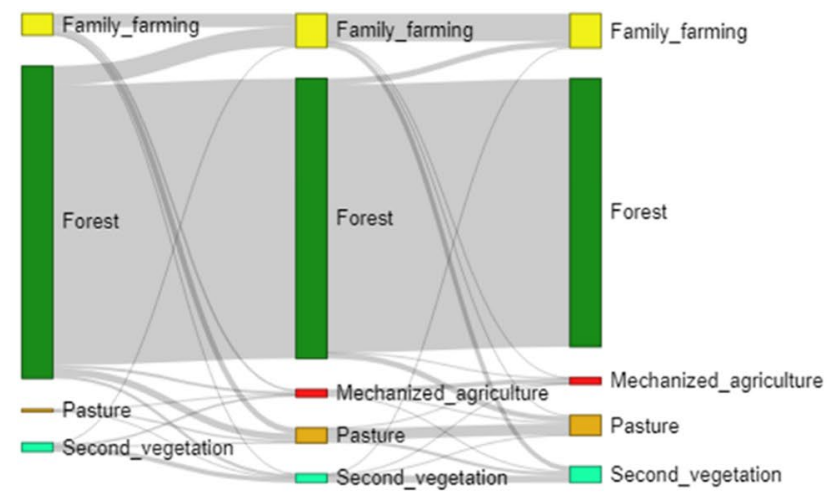

livestock expansion, timber industry, advance of soybeans, and increased mineral exploitation (Folhes et al. 2015; Araújo et al. 2019).

It is important to note that in many of these settlements in the Santarém region, deforested areas were already present before they were created, including those with sustainable use. For example, in the case of ASP and SDP, established as of $2005,7 \%\left(168 \mathrm{~km}^{2}\right)$ of the $2428.32 \mathrm{~km}^{2}$ area was already deforested. Agriculture, secondary vegetation, and pasture occupied $46.67 \%\left(78.45 \mathrm{~km}^{2}\right), 42.15 \%\left(70.85 \mathrm{~km}^{2}\right)$, and $11.18 \%\left(18.79 \mathrm{~km}^{2}\right)$, respectively. Conversely, some of these settlements were created through irregular processes and eventually suspended (Federal Public Ministry. 2007. Civil Public Inquiry n.1.23.002.000185).

\section{What are the underlying land use and land cover dynamics?}

The $75 \%$ increase in the secondary vegetation area during 1999-2015 was accompanied by an intense transition of this class into others, such as mechanized agriculture, pasture, and family farming. This dynamic can partially be explained by the role of secondary vegetation in the development of productive activities in the region. For example, in cattle raising systems, abandoned pastures become secondary vegetation in cattle raising systems. In small-scale family farming systems, slash-and-burn agriculture remains common practice in the forest and subsequently abandoning the area for a period of 2 to 3 years, in order to recover soil fertility through the regeneration of vegetation, before using it again (Schwartz et al. 2017; Costa 2016; Carvalho et al. 2020). However, its resurgence may be another effect of policies and programs in the region, as areas of expanding mechanized agriculture have been embargoed in both inside and outside settlements.

Venturieri et al. (2007), analyzing LULC data for the region from 1975, 1986, 1997, 1999, 2004, and 2005, observed that family farming accounted for $12 \%$ of the deforested area in 1976 and almost 18\% in 2005, whereas

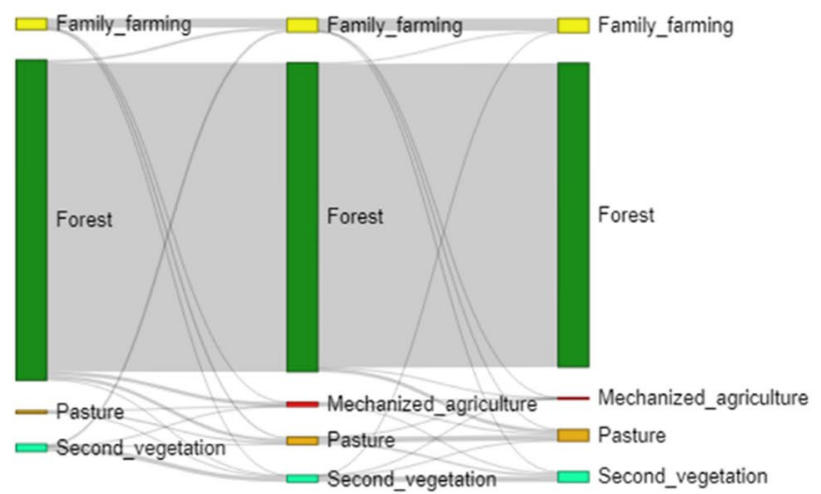

Fig. 3 LULC changes transitions-partitions C and D (1999-2007; 2007-2015) 

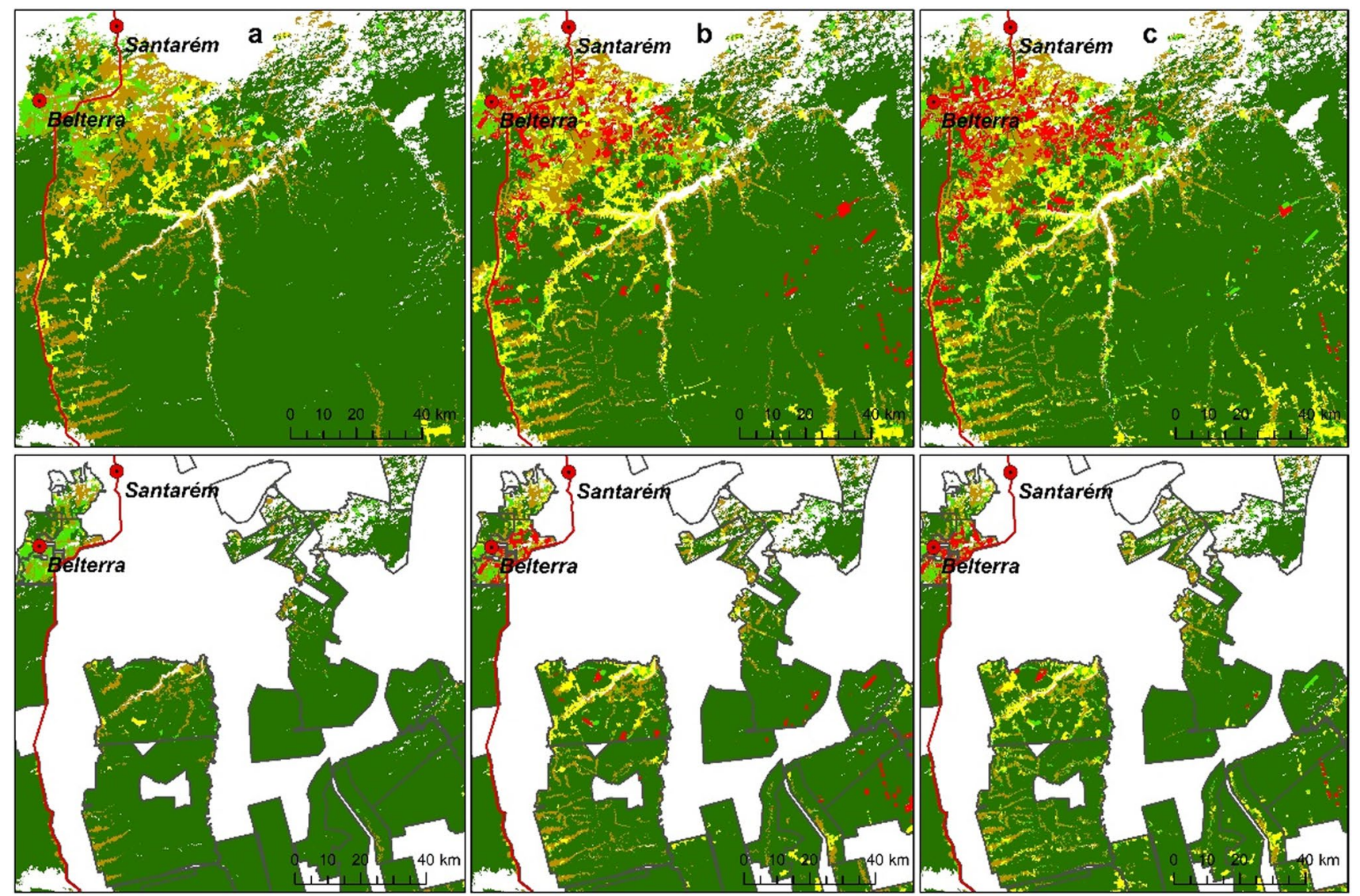

Mechanized agriculture

Family farming

Pasture

Second vegetation

Forest

BR-163 Town

Fig. 4 LULC of the Santarém Region. Classification results for (a) 1999; (b) 2007; and (c) 2015 and LULC in the settlements of the Santarém Region, partitions C and D (1999-2015)

Fig. 5 LULC change transitions - Santarém Region, partition A (1999-2007; 2007-2015)

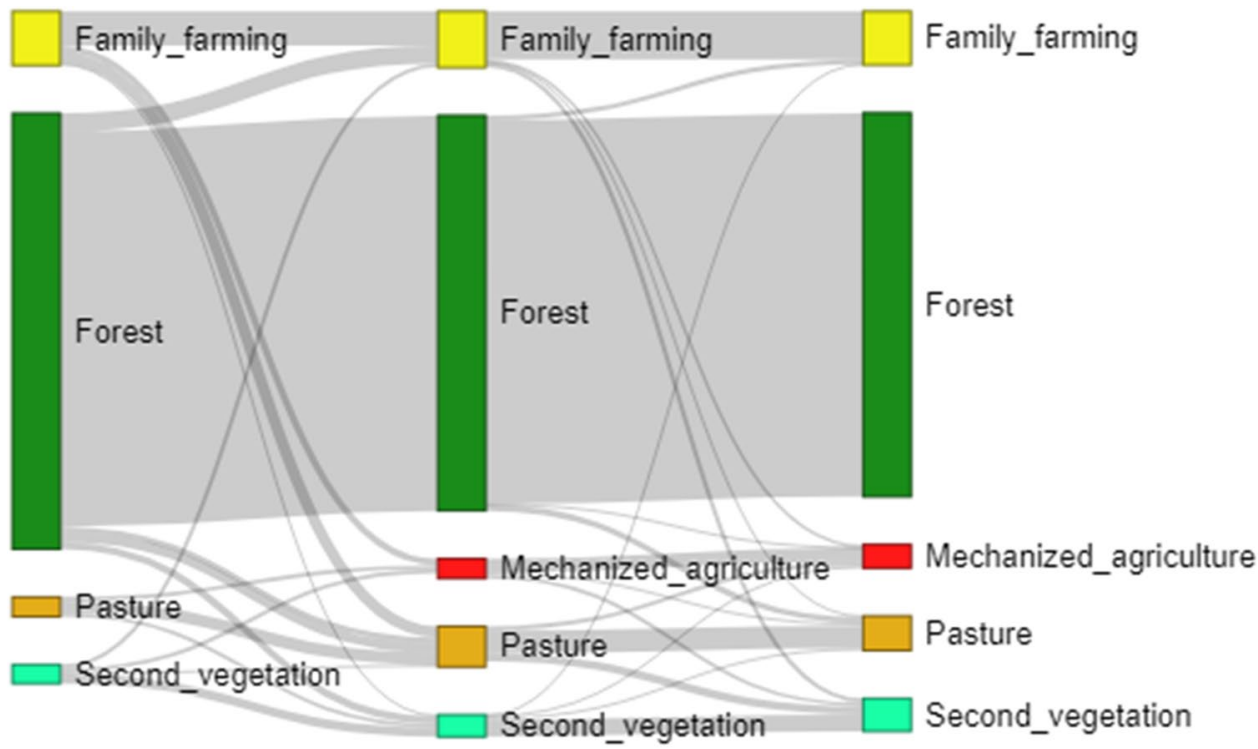


secondary vegetation accounted for $2 \%$ and $16 \%$, respectively. The authors attribute this growth in secondary vegetation to the adopted production system, based largely on the traditional system of cutting, burning, and fallow, corroborated by our results.

The results also showed a $75 \%$ increase in the pasture area during 1999-2015. This increase may be related to the increasing incorporation of soybean sowing on desiccated pasture, which increases organic matter in the soil and allows for crop rotation (Oliveira et al. 2013). This technology consists of implementing an integration between farming and pasture in a high-productivity system, which allows for transition between these two LULC modalities and stimulates their expansion, contrary to what was observed by Venturieri et al. (2007) regarding the tendency of reduction in pasture areas that resulted in the detriment of mechanized agriculture. Based on fieldwork, it is observed that the alternation between uses depends on the advantages offered by the market, which makes the producer choose to intensify his investments in livestock or soy production at a certain moment.

In $2015,42 \%, 12 \%$, and $24 \%$ of mechanized agriculture, secondary vegetation, and pasture-occupied areas were previously used by family farming, respectively. However, in special areas (partitions B and C), family farming grew by $50 \%$, possibly due to the search for new areas by small producers, whose areas were occupied by mechanized agriculture and pasture.

During 2007-2015, the mechanized agriculture area grew very little in the region compared to that during the initial period: $596.93 \mathrm{~km}^{2}$ and $702.48 \mathrm{~km}^{2}$ in 2007 and 2015 , respectively, increasing only $17.68 \%$ from 2007 to 2015 . Although most of the expansion of mechanized agriculture occurred outside settlements, $41.40 \mathrm{~km}^{2}$ were found in 2007, disrespecting the territorial rules of use in these special areas, as discussed before. Soybean plantation areas within settlements that are currently embargoed show an advanced stage of vegetation regeneration. However, this type of crop still occupies $14.38 \mathrm{~km}^{2}$ of the settlement areas (Figs. 4 and 5).

The mechanized agriculture area did not achieve the growth expected by producers in the region, which was estimated to expand over an area of $2000 \mathrm{~km}^{2}$. This expectation was based on a series of transport and logistics infrastructure actions. Among them is the establishment of a route for the outflow of soy production from northern Mato Grosso through the Cargill port terminal, located in Santarém. Other complementary actions included paving of the BR-163 highway, construction of transshipment stations in the municipalities of Itaituba and Rurópolis, and construction of the EF-170 railway, which is part of the export corridor in Brazil through the Arco Norte (PPI, 2017). However, the area of use for mechanized agriculture was restricted to $596.93 \mathrm{~km}^{2}$ and $702.48 \mathrm{~km}^{2}$ in 2007 and 2015 , respectively, which represents an increase of $17.68 \%$.
This demonstrates that mechanized agriculture started to play a secondary role in regional agricultural dynamics, given its role as a flow corridor.

The factors that explain this moderate increase are institutional. Technological advances used in monitoring based on the rules imposed for soy production established by the Soy Moratorium are noteworthy and provide for an embargo on production from newly deforested areas in the Amazon as of July 2006. Other limiting factors were the high production costs in the region and specific technical knowledge to deal with culture in a humid tropical region (Garrett and Rausch 2016; Rudorff et al. 2012).

A third hypothesis of the moderate expansion of extensive soy production is the territorial and land configuration of the region. This agricultural production space is mostly formed by small family farms, in addition to quilombola and indigenous territories. Additionally, the region contains areas with extensive agricultural activity restrictions, such as conservation units and environmentally differentiated settlement projects (Barros et al. 2020; Garrett et al. 2013).

In terms of transitions, $82 \%$ of the mechanized agricultural area in 2015 was found in areas previously opened (42\% previously occupied by family farming, $20 \%$ by secondary vegetation, and $20 \%$ by pasture). Therefore, only $18 \%$ of the mechanized agricultural area came from converted forest areas. This represents only $8 \%$ of the deforested area across the region during 1999-2015. This is explained by the fact that capitalized farmers move to regions with good topography, closer to the city, and specifically, availability of certain levels of formal land ownership proof (Coelho 2009).

As a consequence, although not directly causing deforestation, expansion of this type of monoculture resulted in land concentration and intra-regional population dynamics due to relocation of small farmers and disappearance of communities (Coelho 2009; Venturieri et al. 2007; Bickel 2004; Côrtes and D'Antonna 2016), as discussed below.

Concerning family farming, although it was the class that gave the most area for other uses in the period 1999-2015, the area occupied by it remained stable in the years analyzed, due to its advance of over $921 \mathrm{~km}^{2}$ of forest areas. The growth was $50 \%$ during the period only in special areas (partition C) (Fig. 3).

The expansion of mechanized agriculture over family farming promoted a reconfiguration of the regional agrarian space through population displacement, not only toward the periphery of the cities of Santarém and Belterra, but also toward new areas in the study region. This is evidenced by the $692.48 \mathrm{~km}^{2}$ transitions between forest and family farming between 1999 and 2015. These results corroborate the importance of internal circulation in rural population dynamics in these municipalities (Côrtes and D'Antonna, 2016).

In this context, new communities started to emerge, as is the case of Bom Sossego, at $76 \mathrm{~km}$ of Rodovia BR-163, 
installed in 2004 and formed by former residents of the São Raimundo do Tracoá community. This was extinct after the purchase of small properties by grain producers, and the communities of Jenipapo and Boa Esperança were seriously affected by these activities. All of them are located in the municipality of Belterra (Coelho 2009; Assis 2010).

This is one of the consequences of the coexistence of unequal societies, where those with lower purchasing power and political strength suffer under the power of capital. They are being subjected to search for new forms of reproduction, since they lost not only material bases of their existence and the environmental conditions appropriate to their mode of production, but also their symbolic culture.

\section{Conclusions}

The results presented illustrate how the set of measures adopted to control deforestation have been efficient as well as how their effects differ spatially and temporally, affecting actors and spatial units differently. Further studies are required on other deforestation frontiers before and after the application of control measures. Such studies should ideally integrate an analysis of internal and external migratory flows resulting from different actions and contexts. After remaining relatively stable, deforestation in the Amazon reached its highest value in 10 years in 2018 (INPE 2019). In addition, there is an ongoing debate about canceling the Soy Moratorium (Gibbs et al. 2015).

Understanding the effects of post-2004 actions in different land contexts and situations is essential to elucidate the causes and measures needed to curb their progress, seeking solutions that aim not only to contain deforestation, but also to specifically promote all dimensions of sustainability, "leaving no one behind," as determined by the 2030 Agenda (ONU 2015).

Supplementary Information The online version contains supplementary material available at https://doi.org/10.1007/s10113-021-01821-y.

Acknowledgements We would like to thank the Graduate Program in Environmental Sciences (PPGCA) at the Federal University of Pará (UFPA) for their support in the preparation of this paper.

Funding Open access funding provided by Stockholm University.

Open Access This article is licensed under a Creative Commons Attribution 4.0 International License, which permits use, sharing, adaptation, distribution and reproduction in any medium or format, as long as you give appropriate credit to the original author(s) and the source, provide a link to the Creative Commons licence, and indicate if changes were made. The images or other third party material in this article are included in the article's Creative Commons licence, unless indicated otherwise in a credit line to the material. If material is not included in the article's Creative Commons licence and your intended use is not permitted by statutory regulation or exceeds the permitted use, you will need to obtain permission directly from the copyright holder. To view a copy of this licence, visit http://creativecommons.org/licenses/by/4.0/.

\section{References}

Akabane GK, Lopes CP, Silva FP (2010) O sistema de rastreabilidade para a sustentabilidade no agronegócio brasileiro. Revista Da Micro e Pequena Empresa 4:80-95. https://doi.org/10.6034/170

Araújo R, Vieira ICG, Toledo PM, Coelho AS, Dalla-Nora E et al (2019) Territórios e alianças políticas do pós-ambientalismo. Estudos Avançados 33(95):67-90. https://doi.org/10.1590/ s0103-4014.2019.3395.0006

Araújo R, Léna P (2010) Desenvolvimento Sustentável e Sociedades na Amazônia. Museu Paraense Emílio Goeldi, Belém

Aragão LEOC, Anderson LO, Fonseca MG, Rosan TM, Vedovato LB et al (2018) 21st Century drought-related fires counteract the decline of Amazon deforestation carbon emissions. Nat Commun 9(536):1-12. https://doi.org/10.1038/s41467-017-02771-y

Assis FA (2010) Mercado e produção de terras na Amazônia: avaliação referida a trajetórias tecnológicas. Boletim do Museu Paraense Emílio Goeldi - Ciências Humanas 51 25-39. https://doi.org/10. 1590/S1981-81222010000100004

Assunção J, Gandour C, Rocha R (2013) DETERring deforestation in the Brazilian Amazon: environmental monitoring and law enforcement. Climate Policy Initiative Report. PUC-Rio, Rio de Janeiro. https://climatepolicyinitiative.org/wp-content/uploads/ 2013/05/DETERring-Deforestation-in-the-Brazilian-AmazonEnvironmental-Monitoring-and-Law-Enforcement-TechnicalPaper.pdf. Accessed 05 June 2021

Assunção J, Gandour C, Rocha R (2015) Deforestation slowdown in the Brazilian Amazon: prices or policies? Environ Dev Econ 20:697722. https://doi.org/10.1017/S1355770X15000078

Barros MJB, Canto O, Laurent F, Coelho A (2020) Fronteira agrícola e confl itos territoriais nas Amazônias Brasileiras: a expansão do agronegócio da soja e seus efeitos no planalto de Santarém, ParáAmazônia-Brasil. Ciência Geográfica XXIV 2:893-911. https:// orcid.org/0000-0002-6209-9646

Becker BK (2015) Espaço e desenvolvimento desigual: uma percepção da década de 1970. In: Vieira ICG As Amazônias de Bertha K. Becker: ensaios sobre geografia e sociedade na região amazônica, 1rd edn. Garamond, Rio de Janeiro

Bickel U (2004) Brasil: expansão da soja, conflitos socioecológicos e segurança alimentar Dissertation, University of Bonn

Brito MNS, Guerra GAD (2015) Posseiro ou assentado? Reflexos do processo de interdição de assentamentos no território da Transamazônica e Xingu. Revista IDeAS 9(1):189-226

Carvalho R, Aguiar APD, Amaral S (2020) Diversity of cattle raising systems and its effects over forest regrowth in a core region of cattle production in the Brazilian Amazon. Reg Environ Change 20(44):1-15. https://doi.org/10.1007/s10113-020-01626-5

Castro E (2005) Dinâmica socioeconômica e desmatamento na Amazônia. Novos Cadernos NAEA 8(2):5-39. https://doi.org/ $10.5801 / \mathrm{ncn} . \mathrm{v} 8 \mathrm{i} 2.51$

Coelho A (2009) Modelagem de dinâmica do uso da terra e cobertura vegetal na região de Santarém, Oeste do Pará Dissertation, Federal University of Pará

Côrtes JC, D’Antonna AO (2016) Fronteira agrícola na Amazônia contemporânea: repensando o paradigma a partir da mobilidade da população de Santarém-PA. Boletim Do Museu Paraense Emílio Goeldi Ciências Humanas 11(2):415-430. https://doi.org/10.1590/ 1981.81222016000200005

Costa FA (2016) Contributions of fallow lands in the Inequalities among competing land use deforestation and the agrarian 
economy: Brazilian Amazon to $\mathrm{CO} 2$ balance, trajectories. Elementha: Science of the Anthropocene. https://doi.org/10.12952/ journal.elementa.000133

Ewers RM, Laurance WF, Souza CM (2008) Temporal fluctuations in Amazonian deforestation rate. Environ Conserv 35(4):303-310. https://doi.org/10.1017/S0376892908005122

Folhes RT, Aguiar APD, Stoll E, Dalla-Nora EL, Araújo R et al (2015) Multi-scale participatory scenario methods and territorial planning in the Brazilian Amazon. Futures 73:86-99. https://doi.org/ 10.1016/j.futures.2015.08.005

Garrett RD, Rausch LL (2016) Green for gold: social and ecological tradeoffs influencing the sustainability of the Brazilian soy industry. J Peasant Stud 43(2):461-493. https://doi.org/10.1080/ 03066150.2015.1010077

Garrett RD, Gardner TA, Morello TF, Marchand S, Barlow J et al (2017) Explaining the persistence of low income and environmentally degrading land uses in the Brazilian Amazon. Ecol Soc 22(3):27. https://doi. org/10.5751/ES-09364-220327

Garrett RD, Lambin EF, Naylor RL (2013) The new economic geography of land use change: supply chain configurations and land use in the Brazilian Amazon. Land Use Policy 34:265-275. https:// doi.org/10.1016/j.landusepol.2013.03.011

Gayoso S (2012) Territórios e mercado de terras no baixo Amazonas: expansão da sojicultura e valorização fundiária. VI Encontro Nacional da Anppas Belém. http://www.anppas.org.br/encon tro6/anais/ARQUIVOS/GT18-663-342-20120711090149.pdf. Accessed 16 July 2020

Gibbs HK, Rausch L, Munger J, Schelly I, Morton DC et al (2015) Brazil's Soy Moratorium. Science 347(6220):377-378. https:// doi.org/10.1126/science.aaa0181

IBGE (2018) Produção Agrícola Municipal. Instituto Nacional de Geografia e Estatística. Brasília, Brasil. https://sidra.ibge.gov.br/ tabela/1612. Acessed 20 July 2019

INPE (2019) Monitoramento da Floresta Amazônica Brasileira por Satélite - PRODES: 2017 a 2019. Instituto Nacional de Pesquisas Espaciais. Brasília, Brasil. http://www.obt.inpe.br/prodes/dashb oard/prodes-rates.html. Accessed 6 August 2019

INPE (2021) Taxas de desmatamento - Amazônia Legal - Estados. Terra Brasilis. INPE, São José dos Campos. http://terrabrasilis. dpi.inpe.br/app/dashboard/deforestation/biomes/legal_amazon/ rates. Accessed 05 June 2021

Kalluri S, Grant D, Tucker C, Policelli F, Dykstra J et al (2000) NASA creates global archive of ortho-rectified Landsat Data. Eos 81(50):609-618. https://doi.org/10.1029/EO081i050p00609-02

Mello NGR, Artaxo P (2017) Evolução do Plano de Ação para Prevenção e Controle do Desmatamento na Amazônia Legal Revista do Instituto de Estudos Brasileiros 66: 108-129. https://doi.org/10. 11606/issn.2316-901x.v0i66p108-129

Ministério Público Federal. Procuradoria de Santarém. ICP ${ }^{\circ}$ 1.23.002.000185/2007-76/PRM/STM/MPF.

MMA (2016) Plano de ação para prevenção e controle do desmatamento na Amazônia Legal - Plano Operativo (2016-2020). Ministério do Meio Ambiente. Brasília, Brasil. https://www.mma.gov. br/informma/item/616-preven\%C3\%A7\%C3\%A3o-e-controledo-desmatamento-na-amaz\%C3\%B4nia. Accessed 20 July 2019

MMA (2008a) Instrução Normativa MMA n. 1 de 29/02/2008. Regulamenta os procedimentos administrativos das entidades vinculadas ao Ministério do Meio Ambiente em relação ao embargo de obras ou atividades que impliquem em desmatamento, supressão ou degradação florestal quando constatadas infrações administrativas ou penais contra a flora. Ministério do Meio Ambiente. Brasília, Brasil. https://www.legisweb.com.br/legislacao/?id= 77664. Accessed 20 July 2019

MMA (2008b) Plano Amazônia Sustentável: diretrizes para o desenvolvimento sustentável da Amazônia Brasileira. Ministério do Meio Ambiente. Brasília, Brasil
NASA (2010) Assessment of the NASA - USGS Global Land Survey (GLS) datasets. National Aeronautics and Space Administration. Washington D.C., United States of America. https://www.usgs. gov/land-resources/nli/landsat/global-land-survey-gls?qt-science_ support_page_related_con=0\#qt-science_support_page_related_ con. Acessed 13 June 2020

Nobre CA, Sampaio G, Borma LS, Castilla-Rubio JC, Silva JS et al (2016) Land-use and climate change risks in the Amazon and the need of a novel sustainable development paradigma. PNAS 113(39):10759-10768. https://doi.org/10.1073/pnas.1605516113

Nolte C, Waroux YLP, Munger J, Reis TY, Lambin EF (2017) Conditions influencing the adoption of effective anti-deforestation policies in South America's commodity frontiers. Glob Environ Chang 43:1-14. https://doi.org/10.1016/j.gloenvcha.2017.01.001

Oliveira CM, Santana AC, Homma AKO (2013) Os custos de produção e a rentabilidade da soja nos municípios de Santarém e Belterra, estado do Pará. Acta Amazônia 43(1):23-32. https://doi.org/10. 1590/S0044-59672013000100004

ONU (2015) Transformando nosso mundo: a Agenda 2030 para o desenvolvimento sustentável. Organização das Nações Unidas. https://nacoesunidas.org/wp-content/uploads/2015/10/agend a2030-pt-br.pdf. Accessed 18 August 2019

Panizza AC, Fonseca FP (2011) Técnicas de Interpretação Visual de Imagens. GEOUSP Espaço e Tempo 15 3: 30-43. https://doi.org/ 10.11606/issn.2179-0892.geousp.2011.74230

PPI (2016) Programa de Investimento em Logística (PIL). Programa de Parceria de Investimentos. Ministério da Economia. Brasília, Brasil. http://www.logisticabrasil.gov.br/programa-de-investimento. Internet Archive. https://web.archive.org/web/20160919074014/ http://www.logisticabrasil.gov.br:80/programa-de-investimento. Accessed 6 August 2019

Rivero S, Almeida O, Ávila S, Oliveira W (2009) Pecuária e desmatamento: uma análise das principais causas diretas do desmatamento na Amazônia. Nova Economia 19(1):41-66. https://doi.org/10. 1590/S0103-63512009000100003

Rudorff BFT, Adami M, Risso J, Aguiar DA, Pires B et al (2012) Remote sensing images to detect soy plantations in the Amazon biome -the Soy Moratorium initiative. Sustainability 4:10741088. https://doi.org/10.3390/su4051074

Santos, RP (2010) Os principais fatores do desmatamento na Amazônia (2002-2007): uma análise econométrica e espacial. Dissertation, University of Brasilia

Schwartz G, Falkowski V, Peña-Claros M (2017) Natural regeneration of tree species in the Eastern Amazon: short-term responses after reduced-impact logging. For Ecol Manag 385:97-103. https://doi. org/10.1016/j.foreco.2016.11.036

Song XP, Hansen MC, Potapov P, Adusei B, Pickering J et al (2021) Massive soybean expansion in South America since 2000 and implications for conservation. Nat Sustain. https://doi.org/10. 1038/s41893-021-00729-z

Venturieri A, Coelho AS, Thales MC, Bacelar MDR (2007) Análise da expansão da agricultura de grãos na região de Santarém e Belterra, Oeste do estado do Pará. XIII Simpósio Brasileiro de Sensoriamento Remoto Florianópolis. https://ainfo.cnptia.embrapa.br/digit al/bitstream/item/94124/1/7003-7010.pdf. Accessed 16 July 2020

Walker R, Defries R, Vera-Diaz MC, Shimabukuro Y, Venturieri A (2009) The expansion of intensive agriculture and ranching in Brazilian Amazonia. Geophys Monogr Ser 186:61-81. https:// doi.org/10.1029/2008GM000724

Publisher's note Springer Nature remains neutral with regard to jurisdictional claims in published maps and institutional affiliations. 